\title{
Guest Editorial: THz sensing: Materials, devices, and systems
}

DOI:

10.1109/JSEN.2012.2226647

Link to publication record in Manchester Research Explorer

\section{Citation for published version (APA):}

Hindle, F., Shur, M., Abbot, D., \& Ozanyan, K. B. (2013). Guest Editorial: THz sensing: Materials, devices, and systems. IEEE Sensors Journal, 13(1), 7. [6376143]. https://doi.org/10.1109/JSEN.2012.2226647

\section{Published in:}

IEEE Sensors Journal

\section{Citing this paper}

Please note that where the full-text provided on Manchester Research Explorer is the Author Accepted Manuscript or Proof version this may differ from the final Published version. If citing, it is advised that you check and use the publisher's definitive version.

\section{General rights}

Copyright and moral rights for the publications made accessible in the Research Explorer are retained by the authors and/or other copyright owners and it is a condition of accessing publications that users recognise and abide by the legal requirements associated with these rights.

\section{Takedown policy}

If you believe that this document breaches copyright please refer to the University of Manchester's Takedown Procedures [http://man.ac.uk/04Y6Bo] or contact uml.scholarlycommunications@manchester.ac.uk providing relevant details, so we can investigate your claim.

\section{OPEN ACCESS}


(C2013 IEEE. Personal use of this material is permitted. Permission from IEEE must be obtained for all other users, including reprinting/ republishing this material for advertising or promotional purposes, creating new collective works for resale or redistribution to servers or lists, or reuse of any copyrighted components of this work in other works. 


\section{Editorial}

\section{THz Sensing: Materials, Devices and Systems}

$\mathrm{W}$ ELCOME to this Special Issue dedicated to the use of $\mathrm{THz}$ radiation for sensing. Previously known as the sub$\mathrm{mm}$ or far infrared spectral range, the technological difficulties associated with the fabrication of suitable sources and detectors for $\mathrm{THz}$ frequencies has, until recently, limited their use to a small number of laboratories. The availability of elements like frequency multiplier stages and photoconductive switches, to name only a couple, has now permitted a wider scientific and engineering community to pursue a vast range of objectives using $\mathrm{THz}$ radiation. This was demonstrated by the interest attracted by the first $\mathrm{THz}$ Sensors topical session at the IEEE SENSORS 2011 conference held in October 2011 at Limerick, and lead to the initiation of this Special Issue. The orators at SENSORS 2011 have been requested to submit an enhanced version of their papers, while a general call for papers was opened to a wider community. The objective of this issue is to illustrate the state of the art of $\mathrm{THz}$ techniques with a particular emphasis on its potential to perform sensing tasks.

A significant proportion of the contributions deal with the development and application of complete systems, identifying the fine details of how the potential of $\mathrm{THz}$ waves can be harnessed. A high resolution spectrometer using telecoms lasers has been developed with a heterodyne detection stage. The complete system is able to measure the phase delay results from a single sheet of paper. Alternatively a resonant cavity has been used with an electronic source to greatly increase the instrument sensitivity for molecular spectroscopy. The interaction between $\mathrm{THz}$ radiation and biological material is also addressed, valuable insight into the dynamics encountered are obtained thanks to the high resolution that can now be achieved. Such demonstrations are evidence of the energy and enthusiasm of many researchers using their skills and creativity to tease the benefits offered by this presently under-utilized portion of spectrum.

Approaching the $\mathrm{THz}$ domain from a bottom-up rather than a top-down point of view this Special Issue is also rich in the latest device developments. The highlights include the demonstration of a transistor able to be used as a sub-harmonic mixer in the $\mathrm{THz}$ frequency band. This is accompanied by a paper showing that quantum cascade lasers are not only useful sources but can also simultaneously be used as efficient detection devices.

The papers contained in this Special Issue show that the $\mathrm{THz}$ community is particularly active undertaking a wide range of investigations related to sensing principles and devices.. Although $\mathrm{THz}$ radiation has been proposed to solve a large range of problems it is not a panacea [1]. It does however have some unique properties and so has a role to play in order to satisfy the needs of ever more sophisticated sensing tasks. The future development of $\mathrm{THz}$ waves for sensing will without doubt be thanks to the mutual stimulation provided by workers developing new components, gaining a further understanding of physical processes at $\mathrm{THz}$ frequencies, and demonstrating applications unique to this domain.

The Guest Editors of this Special Issue would like to thank all the authors for the preparation of the manuscripts. We also like to thank the many referees for the time they spent completing the peer reviewing process.

[1] C. M. Armstrong, "The Truth About Terahertz" IEEE Spectrum, vol. 49, no.9, pp 36-41, 2012.

FRANCIS HINDLE Lead Guest Editor

Laboratoire de Physico-Chimie de l'Atmosphère

Université du Littoral Côte d'Opale

francis.hindle@univ-littoral.fr

MicheAL SHUR Guest Editor

Electrical, Computer, \& Systems

Rensselaer Polytechnic Institute

shurm@rpi.edu

DEREK AвBOT Guest Editor

Electrical and Electronic Eng.

University of Adelaide

dabbott@eleceng.adelaide.edu.au

KRIKOR B. OZANYAN Guest Editor

Electrical Eng. \& Electronics

University of Manchester

k.ozanyan@manchester.ac.uk 